\title{
Discussion Methods to Improve Student's Learning Achievement on Social Studies Lessons about Cooperation in Fourth Grade Girimulyo Elementary School
}

\section{Suharto}

SD Negeri Girimulyo

Suhartoharto52@gmail.com

\section{Article History}

accepted 14/11/2020

\begin{abstract}
The purpose of this study was to increase students' achievement in IPS Lesson in students using the discussion method in fourth grade students of Girimulyo Elementary School in 2020/2021. This type of research is the Classroom Piercing Research (PTK) which is carried out in 2 cycles. The stages of each cycle are planning, implementing, observing and reflecting. The author makes observations and provides an formative test in each cycle to determine the development of students. In cycle 1, students who scored above the KKM reached $63 \%$. After the improvement was carried out in cycle 2, the scores of students who reached the KKM were $92 \%$. This result shows that diskcussion methode can increase students' learning achievement in learning of IPS for the fourth grade of SDN Girimulyo..
\end{abstract}

Keywords: Learning achievement, discussion method, IPS

\section{Abstrak}

Penelitian ini bertujuan untuk Meningkatkan prestasi belajar untuk mata pelajaran IPS pada siswa dengan menggunakan meode diskusi. Jenis penelitian yang dilakukan adalah Penelitian Tindalan Kelas (PTK) yang dilaksanakan dalam 2 siklus. Tahapan setiap siklusnya adalah perencanaan, pelaksanaan, observasi dan refleksipenulis melakukan observasi serta memberikan tes formatif dalam setiap siklusnya untuk mengetahui perkembangan peserta didik. Pada siklus 1 peserta didik yang mendapatkan nilai di atas KKM mencapai 63\%. Setelah dilaksanakan perbaikan di siklus 2 nilai peserta didik yang mencapai KKM yaitu 92\% hasil ini menunjukkan bahwa metode diskusi dapat meningkatkan prestasi belajar peserta didik dlam pembelajaran IPS tentang koperasi di kelas 4 SDN Girimulyo.

Kata kunci: Prestasi belajar,metode diskusi, IPS

Social, Humanities, and Education Studies (SHEs): Conference Series https://jurnal.uns.ac.id/shes

p-ISSN 2620-9284

e-ISSN 2620-9292 


\section{PENDAHULUAN}

Pendidikan IPS di sekolah dasar merupakan bidang studi yang mempelajari manusia dalam semua aspek kehidupan dan interaksinya dalam masyarakat. Tujuan pengajaran IPS tentang kehidupan masyarakat manusia dilakukan secara sistematik. Dengan demikian, peranan IPS sangatlah penting untuk mendidik siswa mengembangkan pengetahuan, sikap, dan keterampilan agar dapat mengambil bagian secara aktif dalam kehidupannya kelak sebagai anggota masyarakat dan warga negara yang baik.

Sadirman (2004:2) mengemukakan bahwa interaksi belajar mengajar antara guru dengan siswa sebagai subyek belajar, dalam proses ini guru harus mampu memberikan dan mengembangkan motivasi kepada siswa agar dapat melakukan kegiatan belajar secara optimal. Kreativitas siswa di dalam proses pembelajaran memiliki peranan penting. Dalam keadaan ini siswa tidak hanya sekedar aktif mendengar, mengamati, dan mengikuti, akan tetapi siswa turut terlibat langsung dalam melakukan suatu percobaan, peragaan, dan mendemonstrasikan sesuatu

Berdasarkan hasil wawancara dengan guru dan siswa kelas IV SD Negeri Giirmulyo mengatakan bahwa pembelajaran IPS masih bersifat abstrak. Guru belum menggunakan "metode diskusi" sebagai sarana untuk memperjelas materi dalam proses pembelajaran sehingga membuat pemahaman siswa menjadi rendah. Pembelajaran IPS di sekolah tersebut sejauh ini masih didominasi oleh pembelajaran konvensional. Siswa diposisikan sebagai obyek, siswa dianggap tidak tahu atau belum tahu apa apa, sementara guru memposisikan diri sebagai yang mempunyai pengetahuan. Guru berceramah dan menggurui, otoritas tertinggi adalah guru. Materi pembelajaran IPS diberikan dalam bentuk jadi. Semua itu tidak berhasil membuat siswa memahami dengan baik apa yang mereka pelajari.

Dari hasil observasi juga diperoleh faktor-faktor penyebab kurangnya kreativitas belajar siswa yaitu: 1) Guru lebih menekankan pada terselesaikannya sejumlah materi pembelajaran yang ditetapkan pada silabus dengan alokasi waktu yang tersedia; 2) Siswa dijadikan hanya sebagai objek artinya siswa "dipaksa" menerima seluruh informasi dari guru tanpa diberikan kesempatan untuk melakukan refleksi/perenungan secara logis dan kritis; 3) Guru selalu mendominasi proses pembelajaran dengan menggunakan metode ceramah, sehingga kurang memberi kesempatan pada siswa untuk aktif dan kreatif dalam menuangkan ide dan mempertajam gagasannya; 4) Komunikasi pembelajaran hanya satu arah, kurang adanya interaksi timbal balik antara guru dengan siswa dan antara siswa sendiri;.

Dari hasil penelitian tersebut dapat disimpulkan bahwa penyebab rendahnya hasil belajar IPS adalah kurangnya variasi strategi pembelajaran. Oleh karena itu diperlukan usaha peningkatan kreativitas siswa dalam pembelajaran, yaitu dengan menambah variasi metode pembelajaran yang menarik atau menyenangkan, melibatkan aktivitas dan tanggung jawab siswa. Salah satu metode pembelajaran yang inovatif adalah dengan menggunakan metode pembelajaran diskusi. Seperti yang diungkapkan Bruce Joyce (dalam nana Sudjana, 200:47) mengemukakan empat kategori metode mengajar, yakni metode informasi, metode personal, metode diskusi, dan metode tingkah laku. Pendekatan diskusi menekankan terbentuknya hubungan antara individu / peserta didik yang satu dengan peserta didik yang lain sehingga dalam konteks yang lebih luas terjadinya hubungan sosial individu dengan masyarakat. Mengembangkan kemampuan dan kesanggupan peserta didik untuk mengadakan hubungan dengan orang lain / peserta didik lain, mengembangkan sikap dan prilaku yang demokratis, serta menumbuhkan produktifitas kegiatan belajar peserta didik.

Metode diskusi adalah cara penyampaian bahan pelajaran dengan komunikasi lisan (Hasibuan dan Moedjiono, 1993:13). Begitu juga pasaribu dan Simandjuntak (1986:86) berpendapat bahwa metode Diskusi adalah cara penyampaian nformasi dan 
pengetahuan kepada peserta didik secara lisan, atau tertulis. Metode Diskusi adalah suatu cara penyajian bahan pelajaran dengan cara guru memberi penjelasan dengan dua pihak / lebih untuk mencapai tujuan pengajaran ( Sugito, $1994: 31$ ).

Metode diskusi merupakan rancangan yang menyaluruh mengenai kegiatan belajar mengajar yang dilakukan oleh peserta didik dan kegiatan mengajar yang dilakukan oleh guru didasarkan pada pendekatan (aproach ) dalam mengajarkan suatu materi pelajaran untuk mencapai tujuan pelajaran. (Karo - Karo, 997: 97 - 98) Ada beberapa alasan mengapa guru memakai berbagai macam metode mengajar, diantaranya adalah : (1) menambah pengalaman, (2) mencegah dan mengurangi kelelahan dan kebosanan, (3) membangkitkan minat dan perhatian, (4) membina kerjasama, dan (5) meningkatkan mutu pendidikan dan pengajaran.

Berdasarkan teori diatas dapat disimpulkan bahwa metode diskusi adalah suatu rancangan pembelajaran yang digunakan sebagai sarana penyampaian materi pembelajaran dari dua belah pihak atau lebih yang didasarkan pada pendekatandalam mengajarkan suatau materi, melalui menyediakan masalah sehingga peserta didik mempunyai bahan untuk dipecahkan Bersama dengan tujuan yang sama.

\section{METODE}

Penelitian ini adalah penelitian tindakan kelas (Classroom Action Research) dengan menerapkan metode diskusi. mengacu pada model Kemmis \& Taggart (dalam Trianto, 2010: 30) yang terdiri dari empat komponen yaitu: (1) perencanaan (planning), (2) tindakan (acting), (3) pengamatan (observing), dan (4) refleksi (reflecting). Pada model ini, komponen tindakan dan pengamatan dilaksanakan pada waktu yang sama. Analisis penelitian ini adalah analisis deskriptif kuantitafif kualitatif dimana dalam penelitian ini selain penyajian hasil berupa data maupun angka peneliti juga menentukan bagaimana cara pengolahan hasil penelitian yakni dengan membuat analisisnya dengan menerapkan Media video animasi. Penelitian ini dilaksanakan pada peserta didik kelas IV SD Negeri Girimulyo Tahun Pelajaran 2020/2021 sebanyak 2 sklus secara luring dengan satu kali pertemuan diisetiap siklusnya. Siklus I dilaksanakan pada tanggal 13 Oktober 2020. Siklus II dilaksanakan pada tanggal 20 Oktober 2020. Teknik pengumpulan data yang dilakukan dengan observasi dan tes. Observasi meliputi observasi keterlaksanaan metode diskusi, sikap peserta didik dan motivasi. Untuk hasil belajar menggunakan tes formatif.

\section{HASIL DAN PEMBAHASAN}

Berdasarkan pelaksanaan perbaikan pembelajaran pada siklus pertama prestasi belajar peserta didik dalam proses pembelajaran sudah terlihat. Hal ini tampak dari rekap nilai formatif peserta didik setelah mengikuti kegiatan pembelajaran, motivasi siswa juga sudah mulai meningkat hal ini terliht dalam partisipasi dan antusias peserta idik dalam mengikuti kegiatan belajar mengajar yang dilaksanakan di kelas 4 SDN Girimulyo. Namun ada beberapa siswa yang pasif dan belum berani mengemukakan pendapat, bertanya/menjawab pertanyaan dari guru. Hasil nilai formatif rata-rata mencapai 63\%.

Pada pelaksanaan perbaikan pembelajaran siklus kedua ada peningkatan prestasi belajar peserta didik, dalam pembelajaran kali ini ini tampak pada keaktifan dan antusias mereka dalam berdiskusi walau dalam jarak $1 \mathrm{~m}$ dengan temannya tapi mereka tetap aktif dan semangat menyelesaikan tugas mereka. Peningkatan prestasi belajar dan motivasi peserta didik untuk mempengaruhi tingkat pemahaman siswa sehingga nilai formatif pada siklus kedua ini rata-rata mencapai 93\%.

Hasil analisa prestasi belajar dan motivasi Peserta Didik pada setiap siklus dapat digambarkan sebagai berikut: 
SHEs: Conference Series 3 (3) (2020) 1247- 1252

Tabel 1. Keaktifan Belajar dan Motivasi Belajar

\begin{tabular}{lcccc}
\hline & \multicolumn{2}{c}{$\begin{array}{c}\text { Keaktifan } \\
\text { Belajar }\end{array}$} & \multicolumn{2}{c}{ Motivasi Belajar } \\
\cline { 2 - 5 } & Siklus I & Siklus II & Siklus I & Siklus II \\
\hline Tuntas & 18 & 25 & 19 & 24 \\
\hline $\begin{array}{l}\text { Tidak } \\
\text { Tuntas }\end{array}$ & 10 & 3 & 9 & 4 \\
\hline $\begin{array}{c}\text { Persentase } \\
\text { aktif }\end{array}$ & $64 \%$ & $89 \%$ & $68 \%$ & $86 \%$ \\
\hline
\end{tabular}

Berasarkan tabel di atas dapat penulis gambarkan dalam bentuk diagram sebagai berikut :

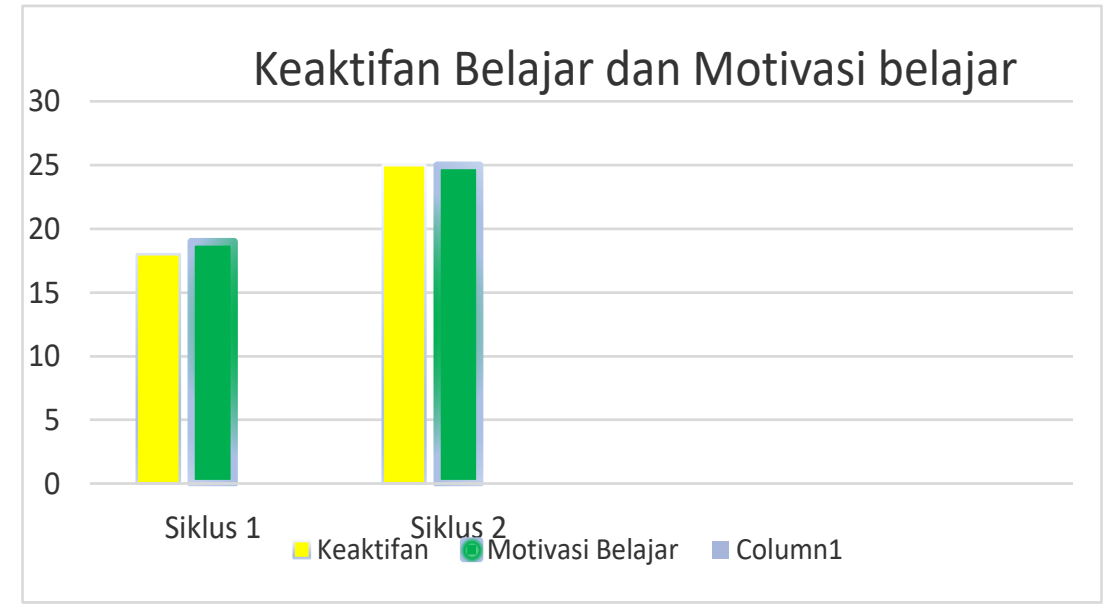

\section{Gambar 1. Keaktifan Belajar dan Motivasi Belajar}

Berdasarkan diagram batang diatas penulis menemukan keaktifan belajar dan motivasi belajar peserta didik mengalami peningkatan yang signifikan, dari siklus 1 peserta didik aktif belajar IPS kelas 4 sub materi Koperasi ada 64\% mengalami peningkatan menjadi $89 \%$ pada siklus 2, Motivasi peserta didik mengalami peningkatan dari siklus 1 ada $68 \%$ meningkat menjadi $86 \%$ hal ini menunjukkan bahwa metode Diskusi mampu meningkatkan keaktifan belajar dan motivasi belajar peserta didik pada IPS tentang Koperasi. berikut :

Adapun prestasi hasil belajar peneliti gambarkan dalam bentuk tabel dan grafik

Tabel 2. Prestasi Hasil Belajar Siswa

\begin{tabular}{|c|c|c|c|c|c|c|c|c|}
\hline & \multirow{2}{*}{$\begin{array}{c}\text { Banyak } \\
\text { soal }\end{array}$} & \multirow{2}{*}{$\begin{array}{l}\text { Skor } \\
\text { maks }\end{array}$} & \multirow{2}{*}{$\begin{array}{c}\text { Jml } \\
\text { siswa }\end{array}$} & \multicolumn{2}{|c|}{ Ketuntasan } & \multirow{2}{*}{$\begin{array}{c}\text { Presentas } \\
\text { e } \\
\text { Ketuntasa } \\
n\end{array}$} & \multirow{2}{*}{$\begin{array}{l}\text { Rata } \\
\text {-rata }\end{array}$} & \multirow{2}{*}{$\begin{array}{c}\text { Present } \\
\text { ase Nilai } \\
\text { Rata- } \\
\text { rata }\end{array}$} \\
\hline & & & & $\mathrm{Ya}$ & Tidak & & & \\
\hline$\underset{I}{\text { Siklus }}$ & 15 & 100 & 28 & 19 & 9 & $68 \%$ & 78 & 78 \\
\hline $\begin{array}{l}\text { Siklus } \\
\text { II }\end{array}$ & 15 & 100 & 28 & 26 & 2 & $93 \%$ & 88 & 88 \\
\hline
\end{tabular}




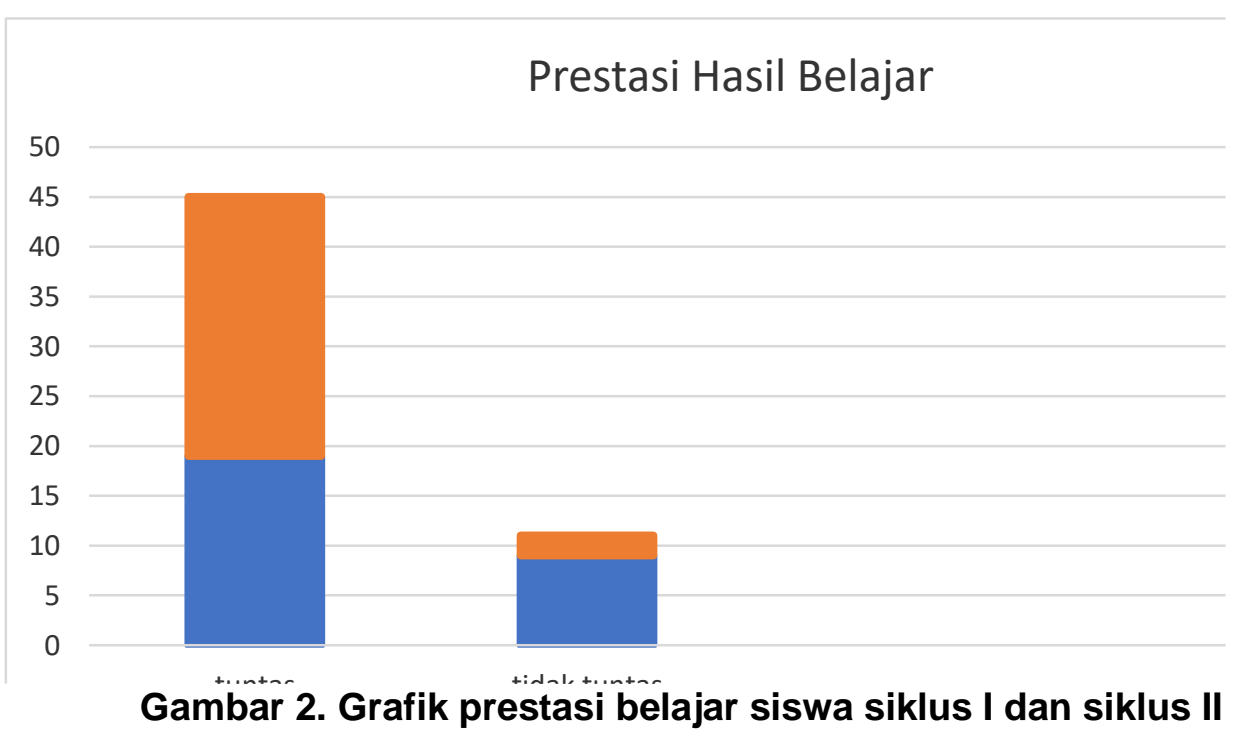

Bedasarkan grafik di atas dapat dinyatakan bahwa Prestasi belajar peserta didik kelas 4 mengalami peningkatan yang signifikan hal ini dapat dilihat dari perolehan nilai peserta didik dari siklus 1 ke siklus 2, di siklua 1 peserta didik yang mencapai KKM (75) sebanyak 19 siswa dari 28 siswa, prosentase sebesar $68 \%$ sedangkan peserta didik yang belum memenuhi Kriteria Ketuntasan Minimal sebanyak 9 peserta didik atau sebesar $32 \%$, berdasarkan nilai formatif yang diberikan peneliti kepada peserta didik di disiklus 2 peserta didik mengalami peningkatan yang cukup signifikan yaitu jumlah peserta didik yang sudah mmencapai KKM sebanayak 26 peserta didik atau $93 \%$ dan jumlah peserta didik yang belum tuntas menurun menjadi 2 peserta didik atau $7.14 \%$

Berdasarkan hasil perbaikaan di 2 siklus yang dilaksanakan selama 12 hari sebanyak 2 kali pertemuan tersebut dapat dipastikan bahwa metode diskusi dapat meningkatkan prestasi belajar peserta didik pada pembelajaran IPS tentang Koperasi kelas 4 SDN Girimulyo Metode diskusi merupakan salah satu metode yang dapat dilaksanakan dalam pembelajaran di sekolah. Efektifitas penggunaanya dapat dilihat dari hasil prestasi peserta didik, yaitu dengan membandingkan mereka yang memakai metode ini dan yang tidak memakainya. Oleh karena itu penggunaan metode ini cukup relevan untuk diteliti mengingat metode ini bisa dilakukan pada semua kalangan tanpa mempertimbangkan usia atau latar belakang. Hanya saja dalam penggunaan metode ini perlu dipertimbangkan segi waktu dan tempat yang representative.

Metode yang baik bukan hanya metode yang mudah untuk dilaksanakan, tetapi metode yang dapat memberikan analisa yang perlu diteliti dan jelas sehingga hasil penelitian tersebut dapat memberikan sumbangan perbaikan. Di dalam penelitian ini penulis menetapkan pilihan penggunaan metode diskusi dalam pembelajaran di Sekolah Dasar. Metode diskusi adalah suatu cara penyajian bahan pelajaran dengan menugaskan peserta didik atau kelompok belajara untuk melaksanakan percakapan ilmiah untuk mencari kebenaran dalam rangka mewujudkan tujuan pengajaran (Karo karo, 1998 : 25). Pendapat tersebut didukung oleh Syaiful Bahri yang menyatakan metode diskusi adalah cara penyajian pelajaran dimana peserta didik dihadapkan kepada suatu masalah yang bisa berupa pertanyaan atau pertanyaan yang bersifat problematis untuk dibahas dan dipecahkan bersama (Bahri, 1997 : 99).

\section{SIMPULAN}

Berdasarkan hasil pengamatan dan tes formatif yang dilaksanakan selama penelitian berlangsung, prestasi belajar kelas IV, yang dijadikan sebagai kelas eksperimen menunjukkan bahwa sebelum menggunakan metode diskusi, hasil 
perolehan prestasi belajar nilai rata-rata yang dicapai oleh peserta didik mayoritas berada pada kisaran antara 64-73. Hal ini diketahui dari nilai hasil belajar peserta didik dalam Tengah semester 1 . Kemudian untuk meningkatkan prestasi belajar mereka di semester berikutnya, dilakukan penelitian pada peserta didik, pada saat pembelajaran IPS dengan menggunakan metode diskusi, hasil belajar mayoritas berada pada kisaran antara 76 - 92. Hal ini menunjukkan bahwa penggunaan diskusi pada mata pelajaran IPS di kelas IV SD Negeri girimulyo Kecamatan Windusari Kabupaten Magelang mengalami peningkatan yang signifikan.

\section{DAFTAR PUSTAKA}

Bahri, Syaiful Djamarah.(1997). Strategi Belajar Mengajar. Jakarta: PT Rineka Cipta. Hassibuan,JJ. Dan Moedjiono.(2006). Proses belajar Mengajar. Banung: CV Remaja Rosdakarya

Kemmis, S. \& Mc. Taggart, R. (1988). The Action Research Planner. Victoria: Deakin University Press.

Nana Sudjana. (2009). Penilaian Hasil Proses Belajar Mengajar. Bandung: PT Remaja Rosdakarya

Pasaribu, I.L. dan B. Simanjuntak. (1983). Proses Belajar Mengajar. Bandung: Tarsito

Sardiman, A.M (2004) Interaksi dan Motivasi Dalam Belajar Mengajar. Jakarta: raja Grafindo Persada.

Sugito, Y. (1994). Dasar-Dasar Agronomi. Malang: Fakultas Pertanian Universitas Brawijaya Malang.

Ulihbukit. (1997). Suatu Pengantar ke dalam Metodologi Pengajaran. Salatiga : C.V Saudara 